\title{
IDENTIFICATION OF GRAIN AREAS REPLACED BY SUGARCANE AND ANALYSIS OF THE RELATIONSHIP WITH FAMILY FARMING PRODUCTION IN THE STATE OF GOIÁS
}

\section{MARIA A. PETRINI ${ }^{1}$, JANSLE V. ROCHA ${ }^{2}$}

\begin{abstract}
In Brazil, the State of Goiás is one of sugarcane expansion's frontiers to meet the growing demand for biofuels. The objective of this study was to identify the municipalities where there were replacement of annual crops (mainly grains) by sugarcane in the state of Goiás, as well as indicate correlations between the sugarcane expansion and the family farming production, in the period between 2005 and 2010. For this purpose, grains crop mask and sugarcane crop mask, obtained from satellite images, were intersected using geoprocessing techniques. It was also used IBGE data of sugarcane production and planted area, and data of family farming production linked with the National Food Acquisition Program (PAA), in relation to the number of cooperatives and family farmers. The crops masks and data tables of the National Food Acquisition Program were provided by National Food Supply Agency. There were 95 municipalities that had crops replacement, totaling 281,554 hectares of grains converted to sugarcane. We highlight the municipalities of Santa Isabel, Iaciara, Maurilândia, and Itapaci, where this change represented more than half of their agricultural areas. In relation to family farming, the sugarcane expansion in the state of Goiás has not affected their activities during the period studied.
\end{abstract}

KEYWORDS: geoprocessing; ethanol; National Food Acquisition Program (PAA).

\section{IDENTIFICAÇÃO DE ÁREAS DE GRÃOS SUBSTITUÍDAS POR CANA-DE-AÇÚCAR E ANÁLISE DA RELAÇÃO COM A PRODUÇÃO AGRÍCOLA FAMILIAR NO ESTADO DE GOIÁS}

RESUMO: No Brasil, uma das frentes de expansão do cultivo da cana-de-açúcar para atender à crescente demanda por biocombustíveis localiza-se no Estado de Goiás. O objetivo principal deste estudo foi identificar os municípios goianos onde houve substituição de culturas anuais (grãos) pela cana-de-açúcar, em Goiás, bem como indicar correlações entre a expansão da cana-de-açúcar e a produção agrícola familiar, no período compreendido entre 2005 e 2010. Para tanto, foi feito um cruzamento entre máscaras de grãos e de cana-de-açúcar obtidas a partir de imagens de satélites e técnicas de geoprocessamento. Também foram utilizados dados do IBGE de área plantada e produção de cana-de-açúcar, e dados de agricultura familiar (número de cooperativas e de agricultores familiares atendidos), vinculados ao Programa de Aquisição de Alimentos (PAA). As máscaras de culturas e as tabelas do PAA foram disponibilizadas pela Companhia Nacional de Abastecimento (Conab). Foram 95 municípios que apresentaram substituição de culturas, totalizando 281.554 hectares de grãos convertidos em cana-de-açúcar. Destacam-se os municípios de Santa Isabel, Iaciara, Maurilândia e Itapaci, onde essa mudança representou mais da metade de suas áreas agrícolas. Quanto à agricultura familiar, a expansão da cana-de-açúcar em Goiás não interferiu em suas atividades durante o período estudado.

PALAVRAS-CHAVE: geoprocessamento; etanol; Programa de Aquisição de Alimentos (PAA).

\footnotetext{
${ }^{1}$ Geógrafa, Doutoranda em Eng. Agrícola, Faculdade de Eng. Agrícola, UNICAMP/Campinas - SP, Fone: (19)3521-1113, maria.petrini@feagri.unicamp.br.

${ }^{2}$ Eng $^{\circ}$ Agrícola, Prof. Dr., Faculdade de Eng. Agrícola, UNICAMP/Campinas - SP, jansle.rocha@feagri.unicamp.br. 


\section{INTRODUCTION}

The increase in world demand for biofuels in recent years has caused the expansion of the cultivation of sugarcane for ethanol production. WALTER et al. (2011) stated that Brazil will continue to be a major producer of ethanol in the global market in the coming years. Ethanol production site conditions are relatively favorable, taking into account factors such as the availability of land and climate, the long-term experience, existing technology and the size of the domestic market. According to HALL et al. (2009), nowadays the sugarcane is the most efficient crop for ethanol production.

In this context, in 2012/2013 harvest, the State of Goiás was the second largest producer of sugarcane and ethanol in Brazil, with 53,136 thousand tons of which 38,646 thousand tons went to fuel production, behind only the State of São Paulo, whose production was of 330,195 thousand tons. Representing one of the fronts of expansion of this crop, Goiás crop of sugarcane in 2012/13 reached 726,000 hectares, which corresponds to an increase of 7\% over the previous harvest. Goiás participates with 8.52\% of the entire area for the cultivation of sugarcane in Brazil (CONAB, 2012).

SPAROVEK et al. (2007), GOLDEMBERG et al. (2008), MARTHA JR. (2008) indicated that the expansion of sugarcane has developed or will push over pasture areas in the Center-South region. In Goiás, there was alternative crops in 75,058 hectares in 2009/10, 61\% of the areas were previously occupied by pasture, $36 \%$ were intended for soybean cultivation and $3 \%$ for corn, which were incorporated into the sugarcane production. (CONAB, 2012a).

On the other hand, NASSAR et al. (2008) reported that in the "Cerrado" biome there is competition, particularly between soybean and/or corn with sugarcane and pasture with sugarcane. Using satellite imagery, the authors showed that $70 \%$ and $76 \%$ of the sugarcane area in Goiás replaced agricultural areas in 2007 and 2008, respectively. AGUIAR et al. (2009) presented data concerning to 2007/08 and 2008/09 harvest seasons of the Center-South region, which reveal that agriculture ceded most of the new areas today occupied by sugarcane, although pasture has had a significant increase in land-use conversion to sugarcane in the States of São Paulo, Minas Gerais and Mato Grosso do Sul. CASTRO et al. (2010) found that the great expansion of sugarcane, especially after 2007, occurred with the incorporation of new planting areas at the expense of the conversion of farmland and pastureland and not by improvements in productivity and it is not clear what are the offsets of crops and livestock in the States targets of this new expansion cycle.

The installation of sugarcane plants in traditional grain-producing regions, as has been occurring in the State of Goiás, can result in impacts on the agricultural production structure, being sometimes necessary a rearrangement and adequacy of infrastructure and logistics of policies geared towards family agriculture, as the Food Acquisition Program (PAA), which was established by the Federal Government in 2003 and is considered a landmark in Brazilian agricultural policy.

Several studies have shown the viability of the use of remote sensing applied to mapping and agricultural monitoring. According to RUDORFF et al. (2010), TM/Landsat 5 images were appropriate for mapping the sugarcane cultivation expansion in the state of São Paulo and identification of land use prior to this expansion, as well as for monitoring the harvest with and without practice of straw burning. FERNANDES (2009) proposed a new method for identification of sugarcane areas in the State of São Paulo from the NDVI temporal profiles of decennials images of the Spot Vegetation sensor. ARAÚJO et al. (2011), using the same sensor, mapped the summer crops in the state of Paraná. LAMPARELLI et al. (2008) compared two soybean mappings in the western Paraná region made with Modis/Terra and TM/Landsat 5 images, estimated by Overall Accuracy and Kappa Index.

The main objective of this study was to identify the municipalities where there were replacement of annual crops by sugarcane in the State of Goiás and quantify these areas, as well as indicate correlations between the expansion of sugarcane and the family agricultural production, in the period between 2005 and 2010. 


\section{MATERIALS AND METHODS}

The study area was the State of Goiás, located in the Central-West region of Brazil. It borders the States of Tocantins, Minas Gerais, Mato Grosso do Sul, Bahia and Mato Grosso. With 340,103 $\mathrm{km}^{2}$, is the seventh State in the country's territorial extension, consisting of 246 municipalities. Goiás is the 9th Brazilian economy and, despite the increasing industrialization, agriculture is still the main responsible for the development of the State. It presents a diversified agriculture composed of soy, cotton, sorghum, corn, sugarcane, beans, and tomatoes (SEGPLAN, 2011).

We used masks of 2009/2010 sugarcane crop and 2007/2008 grain crop (Figure 1), both made and available by the National Food Supply Agency-Conab, which show the respective areas of cultivation in each municipality in Goiás. The mappings of the grain and sugarcane areas are official monitoring data of the agricultural crop of the country, available for viewing and public consultation on the electronic portal project Geosafras (http://geoweb.conab.gov.br/conab/). It is observed that the sugarcane area is mainly in the South and Central Goiás, while most of the grain crop is located in the southern region of the state.

With these masks, it was done the calculation of grain area which was replaced by sugarcane cultivation in order to identify the municipalities where there was a higher expansion of sugarcane over grains. The software ArcGIS 9.3 employed the functions "intersect" of the ArcToolbox and "calculate geometry" of the attribute table.

It were also used tables of Municipal Agricultural Production (table $n^{\circ} 1612$ ), released by IBGE through Sidra - IBGE Automatic Recovery System (www.sidra.ibge.gov.br). The sugarcane planted area and quantity produced data in the period of 2005 to 2010 for the municipalities in Goiás were inserted on attribute table of ArcGIS 9.3 by command "join" and, through the function of selecting by attributes it was possible to identify the municipalities where the area and the production of sugarcane were constants and/or presented increased from one year to the next, from 2005 until 2010. Among these early municipalities identified, were selected those which had also installed plants and cooperatives participants of the PAA in that period, in order to analyze possible interferences of the expansion of sugarcane in the family farming production of these municipalities.

The information gathered about the family farming production linked to the PAA were reviewed and organized in the form of charts and graphs in the software Microsoft Office Excel 2003. The main data source were tables provided by Conab, in which is the registration of cooperatives and proponents associations, of the producers and suppliers and of the products supplied, by mode of PAA, from 2005 to 2010. 


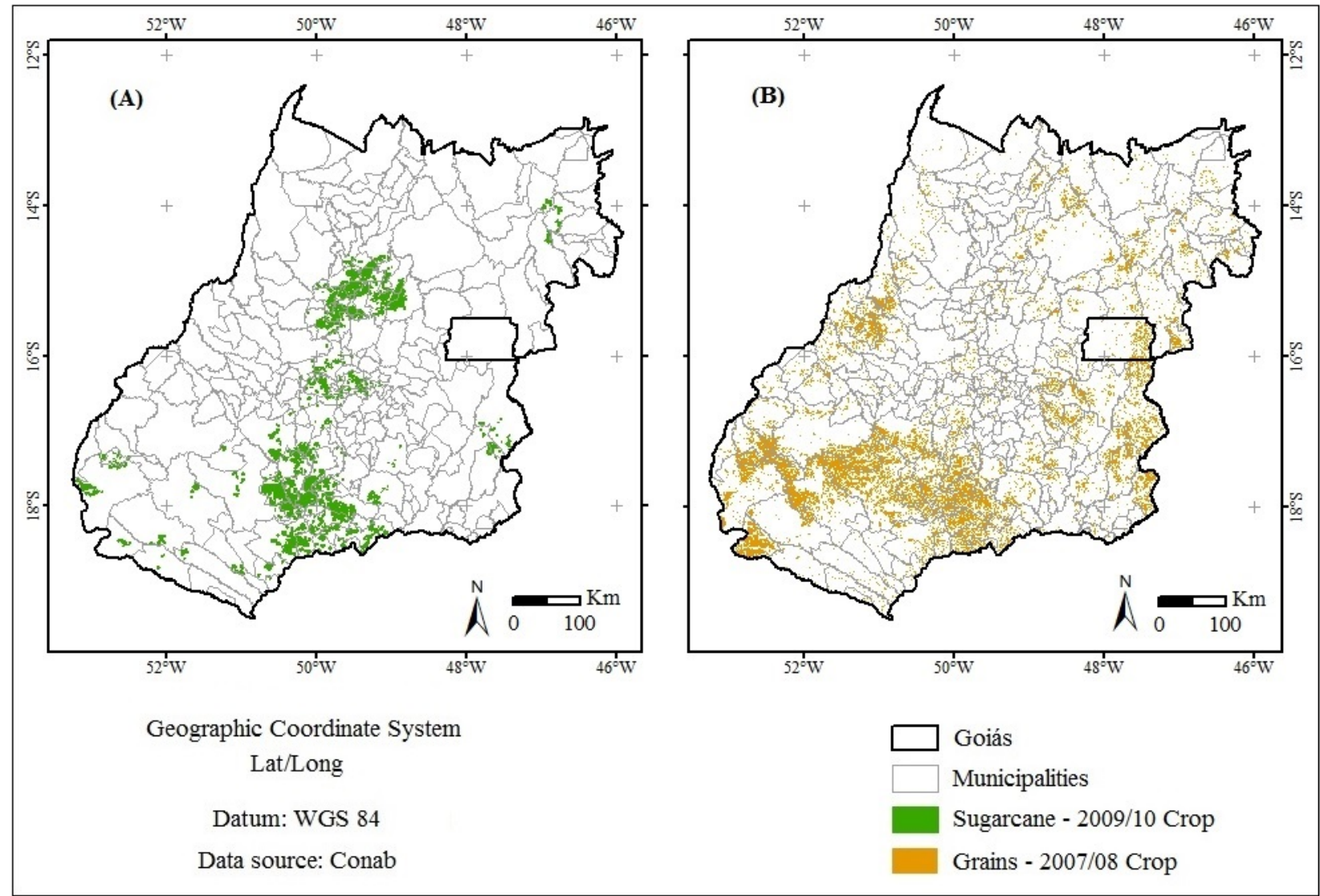

FIGURE 1. Areas of sugarcane and grains mapped by Conab. (A) Sugarcane crop mask. (B) Grains crop mask.

In addition, information was collected directly with some cooperatives as an aid in the analysis of the data of family agriculture front of the expansion of sugarcane. Cooperatives located in municipalities where there are sugar and ethanol plants already installed were chosen for interview. From this criterion, were contacted four cooperatives listed in table 1. The interviews aimed to know the views of participants on the PAA and the installation of sugar and ethanol plants and the expansion of sugarcane in the municipality and its surroundings.

TABLE 1. Cooperatives selected for the interview.

\begin{tabular}{lll}
\hline Municipality & Cooperatives & $\begin{array}{l}\text { Plant / Beginning of } \\
\text { activities }\end{array}$ \\
\hline Jataí & $\begin{array}{l}\text { Coparpa - Cooperativa Mista Agropecuária do Rio Doce } \\
\text { Itapuranga }\end{array}$ & $\begin{array}{l}\text { Coopan / 2009 } \\
\text { Itapuranga }\end{array}$ \\
Rio Verde & $\begin{array}{l}\text { Cooperativa Agropecuária Mista de Produtores Rurais de } \\
\text { Ouroana }\end{array}$ & Vale Verde / 2007 \\
Morrinhos & $\begin{array}{l}\text { Cooperativa Mista dos Agricultores Familiares do } \\
\text { Assentamento São Domingos }\end{array}$ & Camen / 2009 \\
\hline
\end{tabular}

Information obtained directly and indirectly was crossed with the official data from Conab (masks crops) with the aim of inferring the consequences of the expansion of sugarcane in the areas of family farmers participating in the PAA in Goiás. 


\section{RESULTS AND DISCUSSION}

According to the 2007/08 crop mask, the grain area was 4,659,954 hectares, while the area of sugarcane in the mask of the crop 2009/10 was 657,912 hectares. From crossing between them, it became clear where the sugarcane has expanded on grain areas during this period in the State of Goiás. In all, 281,554 hectares of grains, corresponding to $6.1 \%$ of the total area of that crop, turned into sugar plantations spread over 95 municipalities, mainly located in southern Goiás (Figure 2).

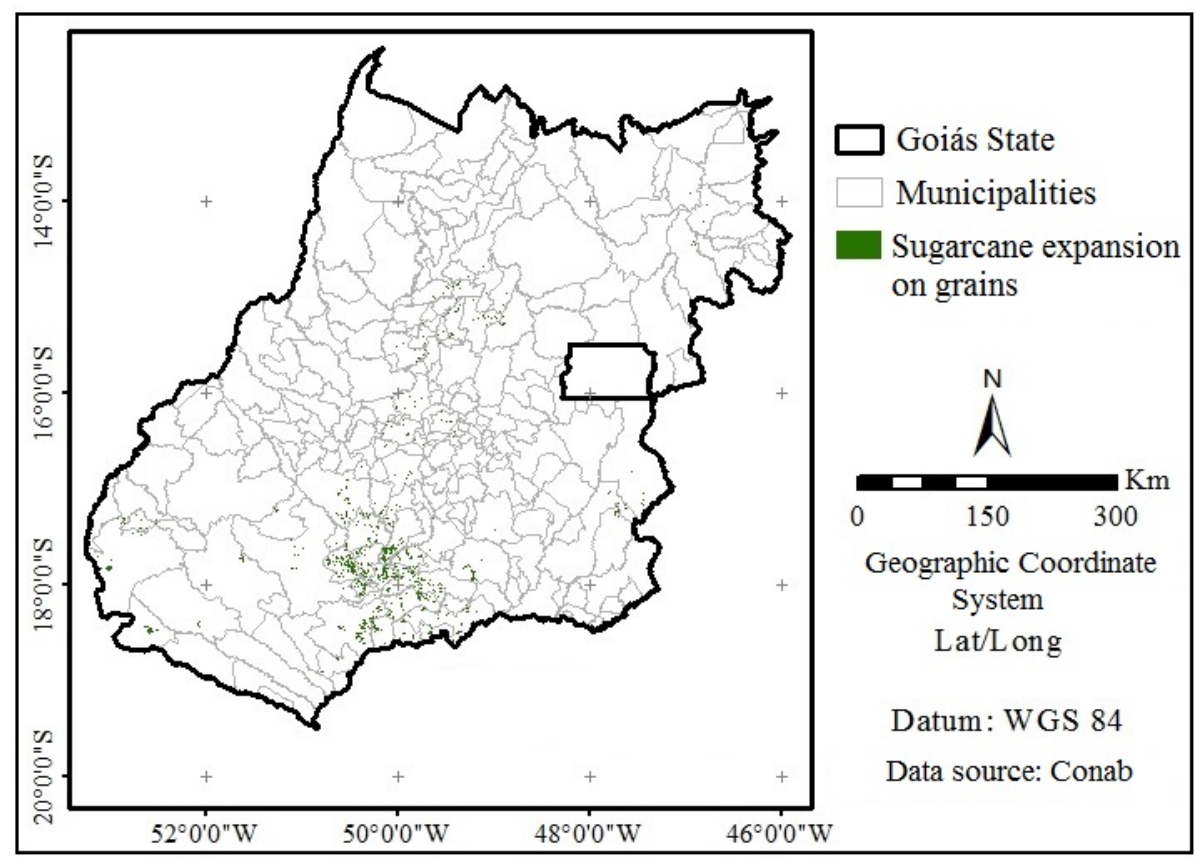

FIGURE 2. Municipalities where there was sugarcane expansion over areas of grains from 2007/08 to $2009 / 10$ harvesting seasons.

Table 2 lists the 26 municipalities in Goiás, in which the grain area replaced by sugarcane exceeded $20 \%$ of the municipal agricultural area. Deserve highlights the municipalities of Santa Isabel, Iaciara, Maurilândia, and Itapaci, which had more than half - 94.3\%; 82.9\%; 59.4\% and $57.7 \%$ respectively - of its agricultural area replaced by the cultivation of sugarcane.

Considering the areas of temporary and permanent crops of 95 municipalities it has the amount of 3,422,012 hectares in 2009, according to IBGE. Thus, the area of grain replaced by sugarcane - 281,554.15 hectares - corresponds to only $8.2 \%$ of this value. It must be assumed, then, that the advance of sugarcane is also on other land uses, mainly pastures. As seen in the literature review, data disclosed by Conab and by researchers from Inpe differ in relation to the areas replaced by sugarcane. As for Conab most areas granted for sugarcane was from pasture (CONAB, 2012a), to NASSAR et al. (2008) and AGUIAR et al. (2009) replaced crops area were from agriculture areas.

In spite of the grains lost little area for sugarcane in total, it is important to do an analysis on local scale, municipality by municipality, because, as shown, there are those who have significant changes and this implies the whole productive structure rearrangement, in addition to changes in the landscape by monoculture, environmental impact, and quality of life, among others. 
TABLE 2. Participation (\%) of the sugarcane expansion over areas of grains in the total of municipal agricultural area.

\begin{tabular}{llll}
\hline Municipalities & $\begin{array}{l}\text { Total municipal } \\
\text { agricultural area (ha)* }\end{array}$ & $\begin{array}{l}\text { Grain area (ha) } \\
\text { replaced by sugarcane }\end{array}$ & $\%$ \\
\hline Santa Isabel & 5183 & 4888.92 & 94.3 \\
Iaciara & 820 & 680.11 & 82.9 \\
Maurilândia & 14210 & 8440.89 & 59.4 \\
Itapaci & 1572 & 907.62 & 57.7 \\
Turvelândia & 35450 & 12687.36 & 35.8 \\
Porteirão & 42835 & 14323.92 & 33.4 \\
Nova Roma & 1498 & 481.76 & 32.2 \\
Gouvelândia & 26030 & 8249.45 & 31.7 \\
Indiara & 14287 & 4243.14 & 29.7 \\
Vicentinópolis & 44435 & 12254.82 & 27.6 \\
Ceres & 1200 & 324.41 & 27 \\
São Luíz do Norte & 10556 & 2777.8 & 26.3 \\
Ipiranga de Goiás & 4315 & 1085.52 & 25.2 \\
Itapuranga & 8885 & 2117.86 & 23.8 \\
Goiatuba & 84139 & 20055.14 & 23.8 \\
Quirinópolis & 67150 & 15669.93 & 23.3 \\
Paranaiguara & 9995 & 2255.2 & 22.6 \\
Edéia & 65893 & 14616.22 & 22.2 \\
Goianésia & 19921 & 4412.6 & 22.2 \\
Jandaia & 17687 & 3906.56 & 22.1 \\
Cachoeira Dourada & 17185 & 3765.18 & 21.9 \\
Rialma & 5545 & 1202.83 & 21.7 \\
Santa Helena de Goiás & 95360 & 20664.8 & 21.7 \\
Acreúna & 52415 & 11278.84 & 21.5 \\
Inaciolândia & 22299 & 4673.33 & 21 \\
Nova Glória & 10420 & 2111.72 & 20.3 \\
\hline * & & &
\end{tabular}

* Municipal Agricultural Production Data 2009 IBGE

Conab's records indicate that 44 cooperatives and associations participated in the PAA at least once between 2005 and 2010, present in 34 municipalities. Figure 3 shows the amount of cooperatives and associations participating in the program in each year. It is observed that the number is increasing over time, in consequence of the disclosure and the growing confidence of family producers in the PAA, with exception for the year 2009. Figure 4 shows the number of family farmers who participated in the PAA in each year. Noteworthy is the year 2006 and 2010, involving 1,220 and 1,097 farmers in total, respectively, but one of these refers to independent farmers, who were not linked to any cooperative or association. 


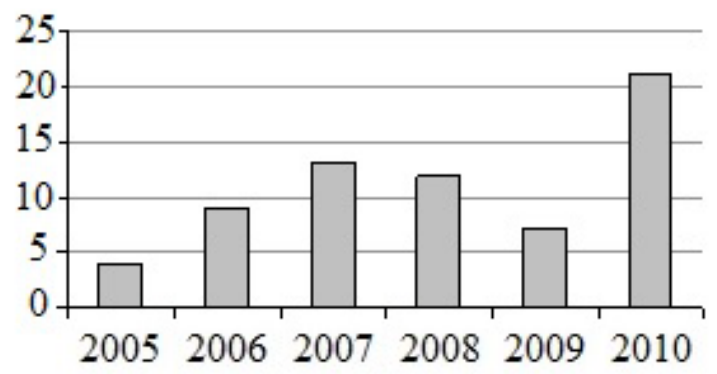

$\square$ Number of cooperatives

FIGURE 3. Number of cooperatives and associations participants in PAA in Goiás between 2005 and 2010.

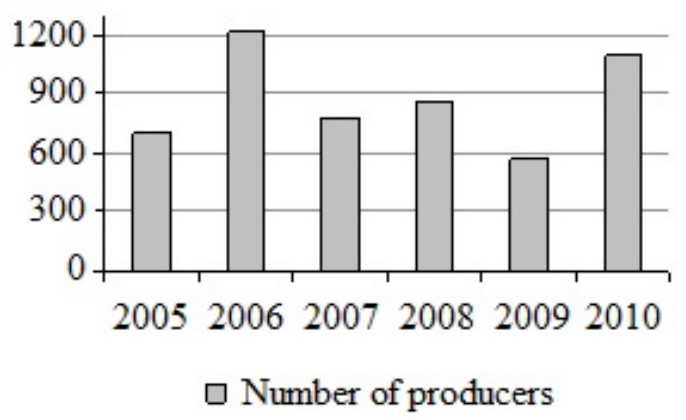

FIGURE 4. Number of family farmers participants in PAA in Goiás between 2005 and 2010.

Figure 5 illustrates the temporal evolution and spatial distribution of the farmers participating in the PAA in Goiás. In 2005, there were more actions of PAA in the Northeast and centre of the State. In 2006, producers of the South and Southwest of Goiás also joined the program, highlighted by the municipalities of Jataí in the South and Niquelândia, in the North. In 2007, the spatial distribution of family farmers is similar to the previous year, except in the southern region of the State. In 2008, a decrease is observed close to the Central, Southeast, and increase in Southwest and East directions, border with Minas Gerais. In 2009, there is a significant decrease in the number of producers, keeping only some concentration in the Central and Northeastern regions. In 2010, there was growth, notably on an axis linking the Southwestern, Central, and Northwest portions.

The data from IBGE of sugarcane planted area per municipality in Goiás, for the years 2005 to 2010, indicate that there was sugarcane expansion in 122 municipalities, most of them located in the Central, South, and Southeast portions in Goiás. Among these municipalities, 19 have cooperatives or associations which in this period participated in the PAA. Table 3 shows the result of this cutting, including the number of family farmers of each municipality that supplied their products to the PAA.

It is observed that the participation of cooperatives and associations in the PAA is quite discontinuous in these municipalities, making difficult the comparative analysis over time. Considering the 19 municipalities, the number of family farmers fell in the years 2007 and 2008. In 2006, out of 714 producers, 255 of them corresponded to individuals of Jataí that were not linked to any cooperative and, therefore, there was this discrepant number compared to other years. In 2009, there is little increase in the amount of producers, and in 2010 the number of family farmers suppliers to the PAA represents more than double the previous year. 


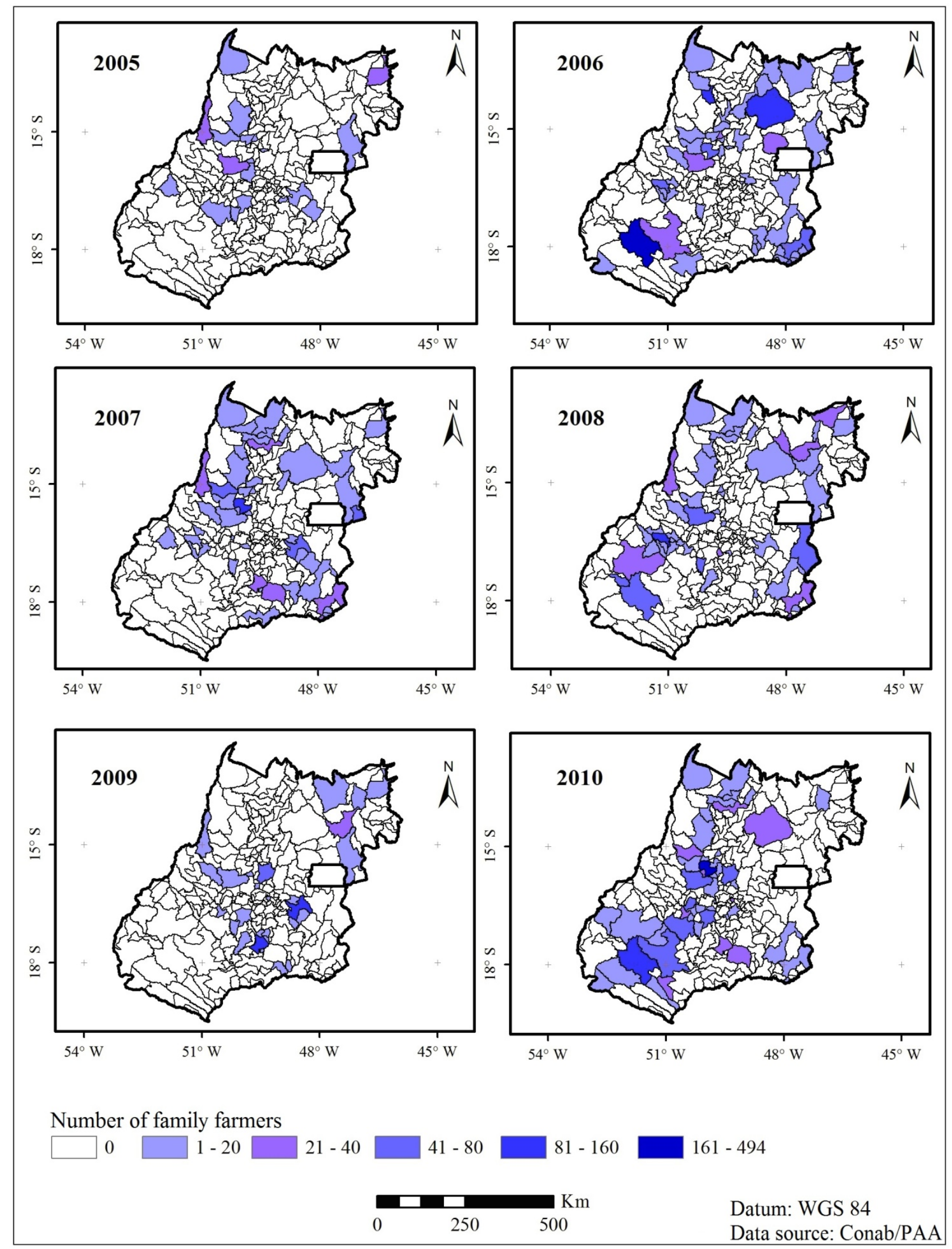

FIGURE 5. Temporal evolution and spatial distribution of family farmers participants in PAA in Goiás, from 2005 to 2010. 
TABLE 3. Municipalities where there were sugarcane expansion between 2005 and 2010 and there are cooperatives/associations participants in PAA, with the respective number of family farmers served by the Program.

\begin{tabular}{llllllllll}
\hline $\begin{array}{l}\text { Municipalities } \\
\text { with cooperatives }\end{array} \begin{array}{l}\text { Number of Family } \\
\text { participants }\end{array}$ & in & \multicolumn{3}{l}{ Farmers participants in the PAA } & \multicolumn{2}{l}{$\begin{array}{l}\text { Increase of sugarcane (\%) in } \\
\text { 2010 compared to 2005 }\end{array}$} \\
\hline PAA & 2005 & 2006 & 2007 & 2008 & 2009 & 2010 & Total & Area & Production \\
\hline Araguapaz & 14 & 14 & 76 & - & - & 25 & 129 & 33 & 33 \\
Buriti Alegre & - & - & - & - & 12 & - & 12 & 100 & 100 \\
Cachoeira Alta & - & - & - & - & - & 22 & 22 & 100 & 100 \\
Caiapônia & - & - & - & 22 & - & 4 & 26 & 133 & 150 \\
Catalão & - & 43 & 26 & 32 & - & 13 & 114 & 300 & 500 \\
Goiás & 26 & 32 & 16 & 60 & 5 & 50 & 189 & 9 & 9 \\
Itapuranga & - & 65 & 159 & - & - & 226 & 450 & 71 & 70 \\
Jataí & - & 494 & - & 50 & - & 131 & 675 & 18847 & 68300 \\
Morrinhos & - & - & 27 & - & - & 21 & 48 & 100 & 100 \\
Nazário & - & - & 15 & - & - & 15 & 30 & 338 & 337 \\
Nova Veneza & - & - & - & - & 18 & 34 & 52 & 51 & 86 \\
Orizona & 5 & - & 6 & - & - & - & 11 & 58 & 50 \\
Padre Bernardo & 4 & 36 & - & - & - & 2 & 42 & 13 & 13 \\
Paraúna & 12 & - & - & - & - & 53 & 65 & 7450 & 15839 \\
Perolândia & - & - & - & 41 & - & - & 41 & 100 & 100 \\
Pontalina & - & - & 37 & - & 125 & 33 & 195 & 100 & 100 \\
Rio Verde & - & 29 & - & - & - & 60 & 89 & 300 & 380 \\
Silvânia & 9 & - & 67 & 4 & 138 & - & 218 & 411 & 440 \\
Uruana & - & 1 & - & - & - & 8 & 9 & 25 & 14 \\
\hline Total & 70 & 714 & 429 & 209 & 298 & 697 & 2417 & - & - \\
\hline
\end{tabular}

The symbol "-" indicates that the municipality had no family farmers served by PAA that year.

The municipalities of Jataí, Itapuranga and Silvânia had the highest number of family farmers who provided the PAA, at the same time that showed significant increases percentage in area $(18 \%$, $71 \%$ and $411 \%$, respectively) and in quantity produced (68\%, $70 \%$ and $440 \%$, respectively) of sugarcane, comparatively between 2005 and 2010.

On the other hand, the municipalities of Goiás and Araguapaz, which also showed great participation in the total showed no significant increase in sugarcane production in that period. The area and sugarcane production grew only 9\% in Goiás and 33\% in Araguapaz.

As a complement to the data submitted by the tables of PAA, the interviews conducted with representatives of selected cooperatives showed, in fact, some contradictions. While the data from Conab reveal discontinuity on the participation of the program over the period analyzed, the interviewees stated that adherence to the PAA is increasing every year, including having continued participation in years that are not recorded in the tables provided by Conab.

It is worth mentioning the case of Coparpa-Cooperativa Mista Agropecuária do Rio Doce, in the municipality of Jataí, in the South of Goias. The cooperative's secretary reported that the main product is the soy destined for biodiesel production for companies like Granol and Caramuru in addition to corn and milk. At the beginning of the operation of the PAA, adhesion of producers was small due to a lack of confidence in the Program and difficulty of drawing up proponents projects delivered to Conab. However, over time, the interest of farmers grew, totaling about 150 farmers enrolled in the PAA in 2011/12 crop. Currently Coparpa provides corn, milk and soy flour.

Regarding to the advancement of sugarcane in the municipality, Coparpa assured that up to this time the sugarcane did not affect the family farming production of the cooperative. In Jataí, besides there being three plants in deployment, there is a unit of Cosan since 2009, which leased 
land near a settlement. The problem is that the road used by the plant for the sugarcane transport is the same in which farmers drain their production being intensely harmed by traffic of heavy trucks. Because of this, the closeness between the lands of the plants and the lands of the producers can be considered the main impact caused by the expansion of sugarcane in Jataí, and will not take long to small producers lease their land for sugarcane production.

Another example is Cooperafi - Cooperative of Farmers of Itapuranga, in the central region of Goiás. The cooperative's manager reported that participation in the PAA has been growing consecutively. The main products currently supplied are fruit and vegetables, with 118 family farmers' cooperative members, however in the projects sent to the program are also included producers who are not members of the cooperative.

Regarding the expansion of sugarcane, the performance of Cooperafi has not been impaired; around $5 \%$ of the cooperative members lease land for the cultivation of sugarcane. According to this cooperative, the plant installed in Itapuranga, Vale Verde, looks for large and medium properties for the leasing of lands, which is not characteristic of the farmers' cooperative members.

In general, the expansion of sugarcane in Goiás did not yet represent a direct threat to family farming linked to the PAA and it is assumed that the advance of sugarcane in the state mainly occurred on other land uses.

\section{CONCLUSIONS}

The crop masks allowed identifying the municipalities producers of grain and sugarcane in the State of Goiás. The intersection between them made possible the identification and quantification of grain area that were replaced by sugarcane between 2007/2008 and 2009/2010 crops. Such areas are located mostly in Southern Goiás. In total, 281,554 hectares spread over 95 municipalities have submitted crop replacement, being Santa Isabel, Iaciara, Maurilândia, and Itapaci municipalities where this change accounted for more than half of its agricultural areas.

The intersection between the PAA and IBGE data of sugarcane expansion area between 2005 and 2010 showed that in the municipalities where there was a strong advancement of sugarcane there was also an increase in the number of family farmers who provided to PAA. Then, we concluded that, in general, it cannot be said that the expansion of sugarcane in Goiás is interfering with family farmers production linked to the PAA, unless the municipality of Jataí, in short term may have some socioeconomic impact, given the context in which it is inserted.

\section{ACKNOWLEDGMENT}

To Capes for the scholarship granted to the first author and to Conab for the availability of data used in this study.

\section{REFERENCES}

AGUIAR, D. A.; ADAMI, M.; RUDORFF, B.F.T.; SUGAWARA, L.M.; FREITAS,R.M. Avaliação da conversão do uso e ocupação do solo para cana-de-açúcar utilizando imagens de sensoriamento remoto. In: SIMPÓSIO BRASILEIRO DE SENSORIAMENTO REMOTO, 14; 2009, Natal. Anais... . São José dos Campos: Inpe, 2009. p. 5547 - 5554. Disponível em: <http://marte.dpi.inpe.br/col/dpi.inpe.br/sbsr@80/2008/11.17.15.20/doc/5547-5554.pdf>. Acesso em: 07 jun. 2010.

ARAUJO, G.K.D.; ROCHA, J.V.; LAMPARELLI, R.A.C.; ROCHA, A.M. Mapping of summer crops in the State of Paraná, Brazil, through the 10-day Spot Vegetation NDVI composites. Engenharia Agrícola, Jaboticabal, v.31, n.4, p.760-770, 2011. 
CASTRO, S.S.; ABDALA, K.; SILVA, A.A.; BORGES, V.M.S. A expansão da cana-de-açúcar no cerrado e no Estado de Goiás: elementos para uma análise espacial do processo. Boletim Goiano de Geografia. Goiânia, v.30, n.1, p.171-191, 2010.

CONAB - Companhia Nacional de Abastecimento. Acompanhamento de safra brasileira: cana-deaçúcar. Terceiro levantamento, dezembro/2012. Brasília: Conab, 2012. Disponível em:

$<$ http://www.conab.gov.br/OlalaCMS/uploads/arquivos/12_12_12_10_34_43_boletim_cana_portug ues_12_2012.pdf> Acesso em: 2 abr. 2013.

CONAB - Companhia Nacional de Abastecimento. Perfil do setor do açúcar e do álcool no Brasil. Edição para a safra 2009-2010. Brasília: Conab, 2012a. Disponível em:

<http://www.conab.gov.br/OlalaCMS/uploads/arquivos/12_05_17_14_53_05_perfil_sucroalcoleiro _2009-2010_versao_marilia.pdf > Acesso em: 2 abr. 2013.

FERNANDES, E. Monitoramento da cultura de cana-de-açúcar no Estado de São Paulo por meio de imagens Spot Vegetation e dados meteorológicos. 2009. 115 p. Dissertação (Mestrado em Engenharia Agrícola) - Universidade Estadual de Campinas, Campinas, 2009.

GOLDEMBERG, J.; COELHO, S.T.; GUARDABASSI, P. The sustainability of ethanol production from sugarcane. Energy Policy, Surrey, n.36, p.2086-2097, 2008.

HALL, J.; MATOS, S.; SEVERINO, L.; BELTRÃO, N. Brazilian biofuels and social exclusion: established and concentrated ethanol. Journal of Cleaner Production, Amsterdam, NL, n.17, p.S77S85, 2009.

LAMPARELLI, R.A.C.; CARVALHO, W.M.O.; MERCANTE, E. Mapeamento de semeaduras de soja (Glycine max (L.)Merr.) mediante dados MODIS/Terra e TM/Landsat 5: um comparativo. Engenharia Agrícola, Jaboticabal, v.28, n.2, p.334-344, 2008.

MARTHA Junior., G.B. Expansão da cadeia de cana-de-açúcar e suas implicações para o uso da terra e desenvolvimento do Cerrado. In: WORKSHOP DO OBSERVATÓRIO DO SETOR SUCROALCOOLEIRO, 1., 2008, Ribeirão Preto. Coletânea de Artigos... Ribeirão Preto: USP/FEA, 2008. v.1, p.221-231.

NASSAR, A.M.; RUDORFF, B.F.T.; ANTONIAZZI, L.B.; AGUIAR, D.A.; BACCHI, M.R.P.; ADAMI, M. Prospects of the sugarcane expansion in Brazil: impacts on direct and indirect land use changes. In: ZUURBIER, P.; VOOREN, J. Van de (Org.). Sugarcane ethanol - Contributions to climate change mitigation and the environment. Wageningen: Wageningen Academic Publishers, 2008. Cap.3, p.63-93.

RUDORFF, B.F.; AGUIAR, D.A.; SILVA, W.F.; SUGAWARA, L.M.; ADAMI, M.; MOREIRA, M.A. Studies on the rapid expansion of sugarcane for ethanol production in São Paulo State (Brazil) using Landsat data. Remote Sensing, Ottawa, v.2, p.1057-1076, 2010.

SEGPLAN - Secretaria de Estado de Gestão e Planejamento e Desenvolvimento. Sepin Superintendência de Estatísticas, Pesquisa e Informações Socioeconômicas. Estado de Goiás. Disponível em: <http://www.seplan.go.gov.br/sepin/goias.asp?id_cad=6000> Acesso em: 30 set. 2011.

SPAROVEK, G.; BERNDES, G.; EGESKOG, A.; FREITAS, F. L.M. de; GUSTAFSSON, S.; HANSSON, J. Sugarcane ethanol production in Brazil: an expansion model sensitive to socioeconomic and environmental concerns. Biofuels, Bioproducts \& Biorefining, Chichester, Inglaterra, v.1, n.1, p.270-282, 2007.

WALTER, A.; DOLZAN, P.; QUILODRÁN, O.; OLIVEIRA, J.G.; SILVA, C.; PIACENTE, F.; SEGERSTED, A. Sustainability assessment of bio-ethanol production in Brazil considering land use change, GHG emissions and socio-economic aspects. Energy Policy, Surrey, v.39, n.10, p.57035716, 2011. 